\title{
Airgun injuries in New Zealand, 1979-92
}

\author{
John D Langley, Robyn N Norton, Jonathan C Alsop, Stephen W Marshall
}

\author{
Abstract \\ Objectives-To describe the epidemi- \\ ology of serious airgun injury in New \\ Zealand.
}

Methods-Cases were selected from the New Zealand Health Information Service's hospital inpatient morbidity data files for the period 1979 to 1992 inclusive.

Results-There were 718 airgun related injuries resulting in 1.56 injuries/100 000 population/year. Males and 10-14 year olds had higher than average rates of injury. The majority of the incidents were unintentional. There has been a marked decline in injury rates since 1989.

Conclusions-Airgun injuries, while not as serious as powder firearm injuries, account for a significant personal and societal burden. The results suggest that strategies aimed at controlling these injuries, especially those pertaining to children, are in need of review.

(Injury Prevention 1996; 2: 114-117)

Keywords: airgun, epidemiology.

The descriptive epidemiology of firearm related deaths and serious injury in New Zealand has recently been described. ${ }^{12}$ That work was stimulated by public debate on firearm control that had largely taken place in the absence of any data on the risks of firearm related deaths or injury. While the focus of the debate and legislation has justifiably been on powder firearms because of their lethality, it is important to note that the Arms Act 1992 also has specific provisions relating to airguns. For example, section 21 of the Arms Act 1983 precludes children being in possession of 'airguns'. While not as lethal, airguns are capable of inflicting serious and permanently disabling injury. ${ }^{34}$ In the course of our earlier study, which sought to determine the incidence of non-fatal powder firearm injuries, ${ }^{2}$ we identified a significant number of airgun injuries. That finding, coupled with the specific provisions of the Arms Act 1992, provided the stimulus for this paper which describes the epidemiology of serious airgun injury in New Zealand.

Auckland, New Zealand.

RN Norton

Injury Prevention Research Center, University of North Carolina at Chapel Hill, Chapel Hill, USA SW Marshall

Correspondence to: Dr JD Langley, Injury Prevention Research Unit,

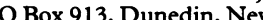
Zealand. defined as any non-powder rifle or handgun that uses air gas to propel lead pellets or steel BBs. Injuries due to powder fired guns, stun guns, flare guns, nail guns, and other such devices were excluded.

Cases were selected from the New Zealand Health Information Service's (NZHIS) hospital morbidity data files for the period 1979 to 1992 inclusive. The NZHIS records data on all public hospital (inpatient) discharges in New Zealand. (The term hospitalisation, versus hospital discharge, is used in this paper for convenience.) Nature and circumstance of injury are coded according to the International Classification of Diseases (ICD).$^{5}$ The hospital morbidity data file makes provision for up to four diagnoses for each case. Injuries are coded according to the ICD injury and poisoning codes. Only admissions with a primary diagnoses of injury (N800-999) were included in the analysis.

This study sought to determine the incidence of airgun injuries. Consequently, readmissions to hospital for the treatment of the same injury were excluded. The data set, however, may have included a limited number of records generated as a result of transfers between hospitals being incorrectly recorded as first admissions.

The nature of the injury event is coded according to the ICD 'Supplementary Classification of External Cause of Injury and Poisoning', commonly referred to as the $\mathrm{E}$ code. The four digit $\mathrm{E}$ code permits the identification and enumeration of victims classified under a variety of categories relating to 'environmental events, circumstances, and conditions'. In addition to the $\mathrm{E}$ code the New Zealand injury morbidity files contain free text descriptions, 30 characters long, of the injury event, and 12 character descriptions of the place of occurrence.

Free text descriptions associated with specific three digit codes were searched electronically using common words that refer to airguns (for example airgun, BB) and common misspellings of these words. Cases with the following three digit $\mathrm{E}$ codes were searched. E917: striking against or struck accidentally by objects (the code designated for unintentional airgun incidents), E922: accident caused by firearm missile, E955: suicide and self inflicted injury by firearms and explosives, E965: assault by firearms and explosives, and E985: injury by firearms and explosives, undetermined whether accidentally or purposively inflicted. All electronically selected cases were reviewed to confirm their eligibility for selection.

Severity of injury was measured on the abbreviated injury scale (AIS). ${ }^{6}$ AIS scores were calculated using a computer programme (ICDMAP) that translates an ICD-9-CM N code diagnosis into an AIS score. ${ }^{7}$ Scores were based on the principal injury diagnosis requiring admission, which is recorded upon dis- 
charge. The validity of the programme ICDMAP has been described elsewhere. ${ }^{8}$ In general, assumptions used to assign AIS scores are conservative. Data on anatomical severity of injury was limited to the period 1988-92 because before 1988 New Zealand's morbidity data was coded according to ICD-9 rather than ICD-9-CM.

Population based incidence rates were calculated using population estimates derived from the New Zealand census of population and dwellings..$^{9-12}$ The population at risk was considered to be all persons resident in New Zealand. Ninety five per cent confidence intervals $(95 \%$ CIs) were constructed using Wilson's approximation. ${ }^{13}$

Table 1 Airgun injuries in New Zealand, 1979-92: sociodemographic characteristics

\begin{tabular}{|c|c|c|c|}
\hline & Frequency & $\%$ & $\begin{array}{l}\text { Rate } 100000 \\
\text { population }(95 \% \text { CI) }\end{array}$ \\
\hline $\begin{array}{l}\text { Gender } \\
\text { Male } \\
\text { Female }\end{array}$ & $\begin{array}{l}611 \\
107\end{array}$ & $\begin{array}{l}85 \cdot 1 \\
14 \cdot 9\end{array}$ & $\begin{array}{l}2.68(2.48 \text { to } 2.90) \\
0.46(0.38 \text { to } 0.56)\end{array}$ \\
\hline $\begin{array}{l}\text { Age group (yea } \\
0-4 \\
5-9 \\
10-14 \\
15-19 \\
20-24 \\
25-29 \\
>29\end{array}$ & $\begin{array}{r}25 \\
74 \\
261 \\
199 \\
73 \\
38 \\
48\end{array}$ & $\begin{array}{r}3 \cdot 5 \\
10 \cdot 3 \\
36 \cdot 4 \\
27 \cdot 7 \\
10 \cdot 2 \\
5 \cdot 3 \\
6 \cdot 7\end{array}$ & $\begin{array}{l}0.68(0.46 \text { to } 1.01) \\
1.99(1.59 \text { to } 2.50) \\
6.55(5.80 \text { to } 7.39) \\
4.72(4.11 \text { to } 5.43) \\
1.86(1.49 \text { to } 2.34) \\
1.03(0.75 \text { to } 1.41) \\
0.21(0.16 \text { to } 0.28)\end{array}$ \\
\hline $\begin{array}{l}\text { Ethnicity } \\
\text { Maori } \\
\text { Non-Maori }\end{array}$ & $\begin{array}{l}117 \\
601\end{array}$ & $\begin{array}{l}16 \cdot 3 \\
83 \cdot 7\end{array}$ & $\begin{array}{l}3.32(2.77 \text { to } 3.98) \\
1.69(1.56 \text { to } 1.83)\end{array}$ \\
\hline $\begin{array}{l}\text { Domicile } \\
\text { Rural } \\
\text { Urban } \\
\text { Unknown }\end{array}$ & $\begin{array}{r}86 \\
399 \\
3\end{array}$ & $\begin{array}{r}12 \cdot 0 \\
55 \cdot 6 \\
0 \cdot 4\end{array}$ & $\begin{array}{l}1.20(0.97 \text { to } 1.48) \\
1.04(0.94 \text { to } 1.14) \\
-\end{array}$ \\
\hline $\begin{array}{l}\text { Year } \\
1979 \\
1980 \\
1981 \\
1982 \\
1983 \\
1984 \\
1985 \\
1986 \\
1987 \\
1988 \\
1989 \\
1990 \\
1991 \\
1992\end{array}$ & $\begin{array}{l}60 \\
49 \\
46 \\
57 \\
55 \\
53 \\
48 \\
52 \\
55 \\
55 \\
57 \\
47 \\
46 \\
38\end{array}$ & $\begin{array}{l}8 \cdot 4 \\
6 \cdot 8 \\
6 \cdot 4 \\
7 \cdot 9 \\
7 \cdot 9 \\
7 \cdot 4 \\
6 \cdot 7 \\
7.2 \\
7 \cdot 7 \\
7 \cdot 7 \\
7 \cdot 9 \\
6 \cdot 5 \\
6 \cdot 4 \\
5 \cdot 3\end{array}$ & $\begin{array}{l}1.92(1.49 \text { to } 2.47) \\
1.56(1.18 \text { to } 2.07) \\
1.46(1.09 \text { to } 1.94) \\
1.79(1.38 \text { to } 2.32) \\
1.71(1.31 \text { to } 2.22) \\
1.63(1.24 \text { to } 2.13) \\
1.46(1.10 \text { to } 1.94) \\
1.59(1.21 \text { to } 2.08) \\
1.66(1.28 \text { to } 2.16) \\
1.65(1.27 \text { to } 2.14) \\
1.71(1.32 \text { to } 2.21) \\
1.39(1.05 \text { to } 1.85) \\
1.33(1.00 \text { to } 1.78) \\
1.09(0.79 \text { to } 1.50)\end{array}$ \\
\hline Total & 718 & 100 & $1.56(1.45$ to 1.68$)$ \\
\hline
\end{tabular}

Table 2 Airgun injuries in New Zealand, 1979-92: circumstances and outcomes

\begin{tabular}{|c|c|c|c|c|}
\hline \multirow[b]{2}{*}{$\begin{array}{l}\text { Intent } \\
\text { Unintentional } \\
\text { Self inflicted } \\
\text { Assault } \\
\text { Undetermined }\end{array}$} & \multirow[b]{2}{*}{$\begin{array}{l}\text { Frequency } \\
689 \\
10 \\
6 \\
13\end{array}$} & \multirow[b]{2}{*}{$\begin{array}{r}\% \\
96 \cdot 0 \\
1.4 \\
0.8 \\
1.8\end{array}$} & \multicolumn{2}{|c|}{$\begin{array}{l}\text { Rate } 100000 \\
\text { population }(95 \% \mathrm{CI})\end{array}$} \\
\hline & & & $\begin{array}{l}1.50(1.39 \\
0.02(0.0) \\
0.01(0.01 \\
0.03(0.02\end{array}$ & $\begin{array}{l}1.62) \\
0.04) \\
0.03) \\
0.05)\end{array}$ \\
\hline $\begin{array}{l}\text { Place of occurrence } \\
\text { Home } \\
\text { Farm } \\
\text { Other premises } \\
\text { Unknown }\end{array}$ & $\begin{array}{r}321 \\
33 \\
66 \\
298\end{array}$ & $\begin{array}{r}44 \cdot 7 \\
4 \cdot 6 \\
9 \cdot 2 \\
41 \cdot 5\end{array}$ & & \\
\hline $\begin{array}{l}\text { Injury (ICD codes) } \\
\text { Open wound of lower limb }(890-897) \\
\text { Open wound of upper limb }(880-887) \\
\text { Eye injuries }(870,871,918,921,930) \\
\text { Head injuries }(801,802,850,854,872 \text {, } \\
873,874,910) \\
\text { Others }\end{array}$ & $\begin{array}{r}224 \\
183 \\
126 \\
107 \\
78\end{array}$ & $\begin{array}{l}31 \cdot 2 \\
25.5 \\
17 \cdot 5 \\
14 \cdot 9\end{array}$ & $\begin{array}{l}\text { Daystay } \\
703 \\
230 \\
483 \\
187\end{array}$ & $\begin{array}{l}\% \\
37 \cdot 1 \\
12 \cdot 1 \\
25 \cdot 5 \\
9 \cdot 9\end{array}$ \\
\hline Total & 718 & 100 & 1894 & 100 \\
\hline
\end{tabular}

Subjects were classified into urban or rural residences as of 1991 on the basis of the domicile code included on the hospitalisation file. A translation key which assigned each domicile code to either an urban or a rural area was provided by the Ministry of Health.

\section{Results}

Between 1979-92 there were 718 airgun injuries, an average of $51 /$ year. The crude morbidity rate of the study period was 1.56 injuries/100 000 person years (95\% CI 1.45 to $1 \cdot 68)$. Table 1 contains details of the distribution of these events by sociodemographic characteristics of the victims and the annual totals. Table 2 summarises the injury circumstances and outcomes.

Males were victims in $85 \%$ of the incidents and their rate was nearly six times that for females. Half of all the incidents involved children $(<15$ years), and those aged 10-14 years had the highest rate of all age groups. Maori were victims in $16 \%$ of events and the crude rate for Maori was two times that for non-Maori. Persons whose domicile was classified as rural had a slightly higher rate of injury than urban residents, but the large overlap in the $95 \%$ CIs suggest that this difference was unlikely to be statistically significant.

The figure shows that during the 1980s the rates of injury were relatively constant. 1990 saw the start of a marked downward trend in rates. Unintentional injuries accounted for $96 \%$ of the incidents.

The 718 incidents resulted in 1894 hospital bed days. The most common (186) injuries were open wounds to the lower limbs. Forty two per cent involved the knee, lower leg, or ankle, and a further $35 \%$, the foot and toes. Sixty seven per cent of the upper limb open wounds involved the hand or fingers. Injuries to the eye and surrounding tissue were of particular significance because they accounted for $17.5 \%$ of the inidents yet $25.5 \%$ of bed days usage. Thirty eight of these involved injury to the eyeball.

Injury severity scores were available for 243 cases and the majority $(80 \%)$ were classified as AIS-2.

\section{Discussion}

At an average of 51 cases/year, airgun injuries are not common relative to other causes of injury. The early 1990s has seen a steady decline in the incidence of these injuries, despite the fact that we are unaware of any specific interventions that may account for this. Given that children are typically involved in these incidents, one possible explanation is that greater parental control is being exercised in direct response to the public's concern about firearm safety.

While airgun or air rifle inflicted injury is less likely than powder firearm injury to be fatal, the use of these firearms has, nevertheless, resulted in substantial personal and societal losses. Moreover, there is increasing concern that 


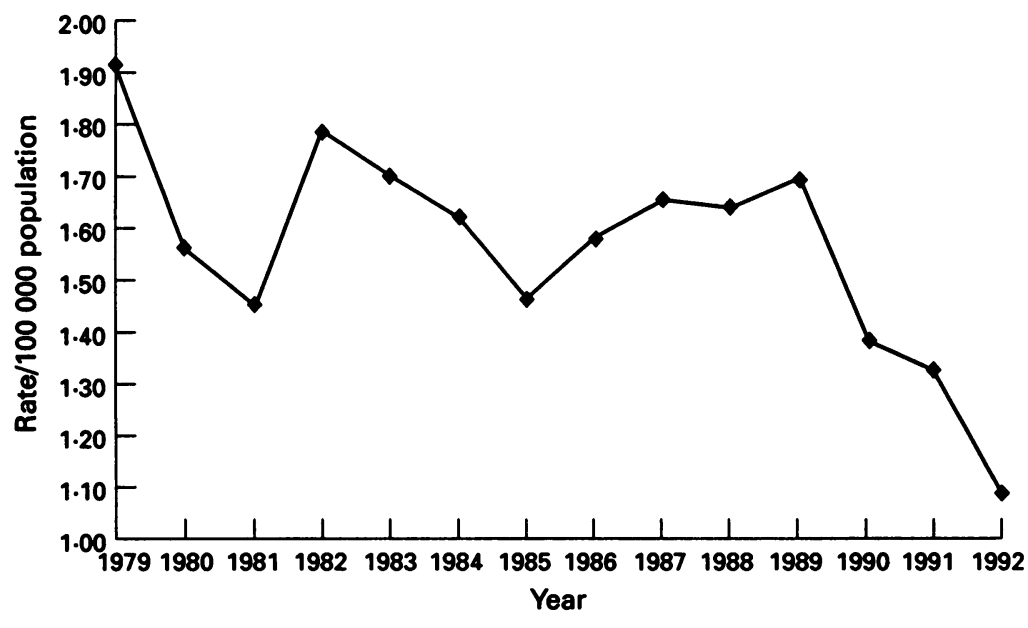

Airgun injuries in New Zealand, 1979-92. presented here suggest that either supervision of persons under 18 has been inadequate, or that persons over 18 have been discharging airguns in an irresponsible manner, or both. The reasons for either situation remain speculative, but one possible explanation is ignorance of the law and of safety practices. Media attention and educational material on the safe use of firearms in recent times has focused mainly on powder firearms. Another possible explanation is lack of enforcement: unintentional airgun incidents are less likely to come to the attention of the police, given their relative lack of lethality and the quietness of discharge.

Under present regulations persons over 18 years do not have to hold a firearm licence to own an airgun or air rifle. The historical rationale for this exemption relates to the latter's relative lack of lethality. In recent years, however, airguns have become increasingly more powerful. Airguns with muzzle velocities of $1000 \mathrm{feet} / \mathrm{second}$ are more commonly available. 'These arms are not toys and a far cry from airguns of years ago. The new air rifles are capable of causing serious wounds or even a killing shoot on a human .....${ }^{17}$ As a consequence, airguns represent an attractive alternative to, say, a .22 rifle for pest control in that, unlike the .22 rifle, a licence is not required..$^{17}$

In addition to compliance and enforcement obligations, the New Zealand police have a responsibility to facilitate the safe use of firearms. Most of this work is carried out on their behalf by the New Zealand Mountain Safety Council (NZMSC). NZMSC recently established a research committee. We have already recommended that the committee give priority to determining what data elements would constitute a minimum data set for firearm injury and fatality, and how a national data set could be established and maintained. ${ }^{2}$ Given the results presented here, we wish to emphasise that the committee also include airguns in their brief.

Half of the injuries in this series involved children $(<15$ years). Children injured either shot themselves, were shot by another child or an adult, or were the victim of a ricochet. Unfortunately, we were unable to ascertain this type of information from the electronic records. A recent report by Schein et al on 140 airgun inflicted ocular injuries in the US found that $95 \%$ were inflicted by individuals known to the victim, and $40 \%$ of these were relatives. ${ }^{16}$ Moreover, people were the intended targets in $45 \%$ of the injuries, and ricochets only accounted for $26 \%$ of the injuries. Of victims with penetrating ocular injuries, $84 \%$ had subsequent visual acuity of less than $20 / 200$ despite repeated surgery. The mean age of these victims was 13 years. Adults were present at the scene in only $11 \%$ of incidents. Whether the New Zealand situation is similar is a matter of conjecture.

Section 21 of the Arms Act 1983 precludes children being in possession of 'airguns'. whereas section 22 states that 'it is a good defence' if one proves the firearm was being used under the immediate supervision of someone with a firearm licence. The results

\section{Implications for prevention}

In summary, although not as common or serious as powder firearm injuries, airguns cause considerable unnecessary personal and societal losses, especially among children and to their eyes. The results presented here suggest a review of legislative provisions, enforcement, and educational strategies is warranted, especially in light of increasing potential for some of these airguns to inflict serious injury. Such a review needs to consider if the reduction in the early 1990s is sustained in the mid-1990s.

The Injury Prevention Research Unit and the Injury Prevention Research Centre are both jointly funded by the Accident Rehabilitation and Compensation Insurance Corporation, and the Health Research Council of New Zealand. The injury statistics were provided by the New Zealand Health Information Service. The authors wish to acknowledge the advice of Lee Annest, Philip Alpers, Bob Badland, and John Coote in the preparation of this paper, and Pam Jemmett for assisting in the preparation of this paper, and Partion of the manuscript.
preparat.

1 Norton R, Langley JD. Firearm deaths in New Zealand, 1978-1987. NZ Med f 1993; 106: 463-5. 
2 Langley JD, Marshall SW, Norton RN. Non-fatal firearm injuries in New Zealand 1979-92. Ann Emerg Med (in press).

3 Lucas RM, Mitterer D. Pneumatic firearm injuries: trivial trauma or perilous pitfalls? F Emerg Med 1990; 8: 433-5.

4 Ford EG, Senac MO Jr, McGrath N. It may be more significant than you think: BB air rifle injury to a child's head. Pediatr Emerg Care 1990; 6: 278-9.

5 World Health Organisation. International classification of diseases, 1975 revision. Geneva: World Health Organisation, 1975.

6 Committee on Injury Scaling. The abbreviated injury scale, 1985 revision. Des Plaines, IL: Association for the Advancement of Automotive Medicine, 1985

7. The Johns Hopkins Health Services Research and Development Center and the Maryland Institute for Emergency Medical Services System. ICDMAP - determining injury severity for hospital discharges: a program to map ICD-9CM diagnoses into AIS and ISS severity scores. Baltimore: Development Center, The Johns Hopkins University, 1988.

8 MacKenzie E, Steinwachs D, Shankar B. Classifying trauma severity based on hospital discharge diagnoses. Med Care 1989; 27: 412-22.

9 Department of Statistics. New Zealand standard classification of occupations 1990. Wellington: Department of Statistics, 1992
10 Department of Statistics. New Zealand census of population and dwellings 1981, regional statistics series, bulletin 10 , regional summary. Wellington: Department of Statistics, regional.

11 Department of Statistics. 1986 New Zealand census of population and dwellings, usually resident population, series $B$ report 25. Wellington: Department of Statistics, 1987

12 Department of Statistics Te Tari Tatau. 1991 New Zealand census of population and dwellings, New Zealand's population structure. Wellington: Department of Statistics Te Tari Tatau, 1992.

13 Wilson EB. Probable inference, the law of succession and statistical inference. Fournal of the American Statistical Association 1927; 22: 209-12.

$14 \mathrm{McNeill}$ AM, Annest JL. The ongoing perils of BB and pellet gun injuries in the United States. Ann Emerg Med (in press).

15 National Center for Injury Prevention and Control. Centers for Disease Control firearm injury surveillance study, fune Injury Prevention and Control, Centers for Disease Injury Prevention and Control

16 Schein OD, Enger C, Tielsch JM. The context and consequences of ocular injuries from airguns. Am $\mathcal{F} O$ phthalmol 994; 117: 501-6.

17 Axbey W. Kid stuff? No way! New Zealand Guns 1994; 23: $56,57,59$.

\section{Editorial Board Member: brief biography}

TERRY NOLAN

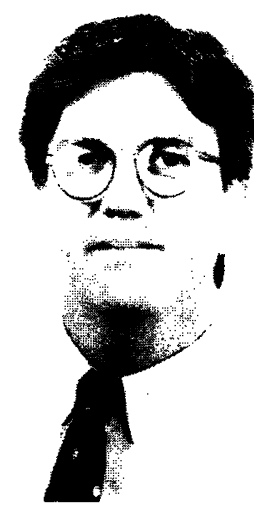

Terry Nolan is an Associate Professor of Paediatrics at the University of Melbourne and a paediatrician at the Royal Children's Hospital. There, he is head of the Clinical Epidemiology and Biostatistics Unit. His medical degrees are from the University of Western Australia, and his $\mathrm{PhD}$ in Epidemiology and Biostatistics was completed at McGill University in Montreal in 1986. He is a Fellow at the Royal Australasian College of Physicians and a Fellow of the Faculty of Public Health Medicine in that college.

He established the Victorian Injury Surveillance System in 1988. More recently, he has helped establish the Victorian Emergency Department Minimum Dataset (VEMD), which is a model for emergency department based injury surveillance embedded in routine emergency department electronic data collection systems.

In addition to research arising out of child injury surveillance and the development of surveillance systems, he has been involved in a number of projects including community interventions to reduce injury in family day care, research on sporting injuries in children and adolescents, studies related to the prevention of bicycle injuries, and asphyxiation and burn injuries in children.

Dr Nolan was Chairman of the Scientific Program Committee for the recently completed Third International Conference on Injury Prevention and Control held in Melbourne. 